\title{
THE METROPOLITAN TORONTO PLAN
}

\section{James B. Milner †}

The federation in 1953 of thirteen municipalities in the Toronto metropolitan area represents the first successful attempt in North America to incorporate a federal municipality that shares with its constituent municipalities the legislative and executive powers of local government. It was successful politically, but only the future can tell whether it was a functional success or merely a step toward some more permanent and functionally successful form of government not yet established. It is the purpose of this article to describe and assess the history of this experiment in federation. The article is divided into four parts: The Metropolitan Problems; Administrative Attempts at a Solution; The Ontario Legislature's Solution; Planning and the Future.

\section{The Metropolttan Problems}

The problems of local government in the Toronto metropolitan area did not differ materially from those in any metropolitan area in North America. ${ }^{1}$ They derived essentially from the inability of the thirteen existing municipal governments to engage in concerted action to solve their obviously common problems, such as arterial road construction; from the financial inability of individual municipalities to provide obviously local services, such as schools; and from the widely recognized fact that many of the local services could be most efficiently supplied only on an area basis, that is, that they too were common problems, such as cooperation in many aspects of police administration.

If there could be said to have been any problem peculiar to the Toronto area it would be the water supply and sewage system, since all water must come from Lake Ontario and all sewage drain into it, and because six of the thirteen municipalities are separated from Lake Ontario by the city of Toronto or the village of Swansea. The financial difficulties of the municipalities were the most demanding of solution. As may be seen from the accompanying table, ${ }^{2}$ the tax bases in the area

$\dagger$ Associate Professor of Law, University of Toronto. LL.B., 1939, Dalhousie University; LL.M., 1950, Harvard University.

1. See Committee on Metropolitan Problems, Civic Advisory Council of Toronio, FIRST REPORT (2 sections 1949-1950) and Final REPORT (1951), for the most comprehensive survey of Toronto metropolitan problems available. See also CIVIC ADvisory CouncIL OF TORONTO, MUNICIPAL FINANCE (1950). On the general problem, see Chapman \& Putham, The Physiography of Southern OnTarto (1951); SPELT, THE URBAN DEVELOPMENT IN SOUTH CENTRAL ONTARTO (1955) (a geographer's history of the area).

2. See p. 571 infra. 
are uneven, due mainly to the dormitory character of many of the suburbs. Apart from Toronto, which has a comfortable ratio of sixtyone per cent industrial and commercial assessment, only four of the suburban municipalities have a satisfactory ratio, although this factor

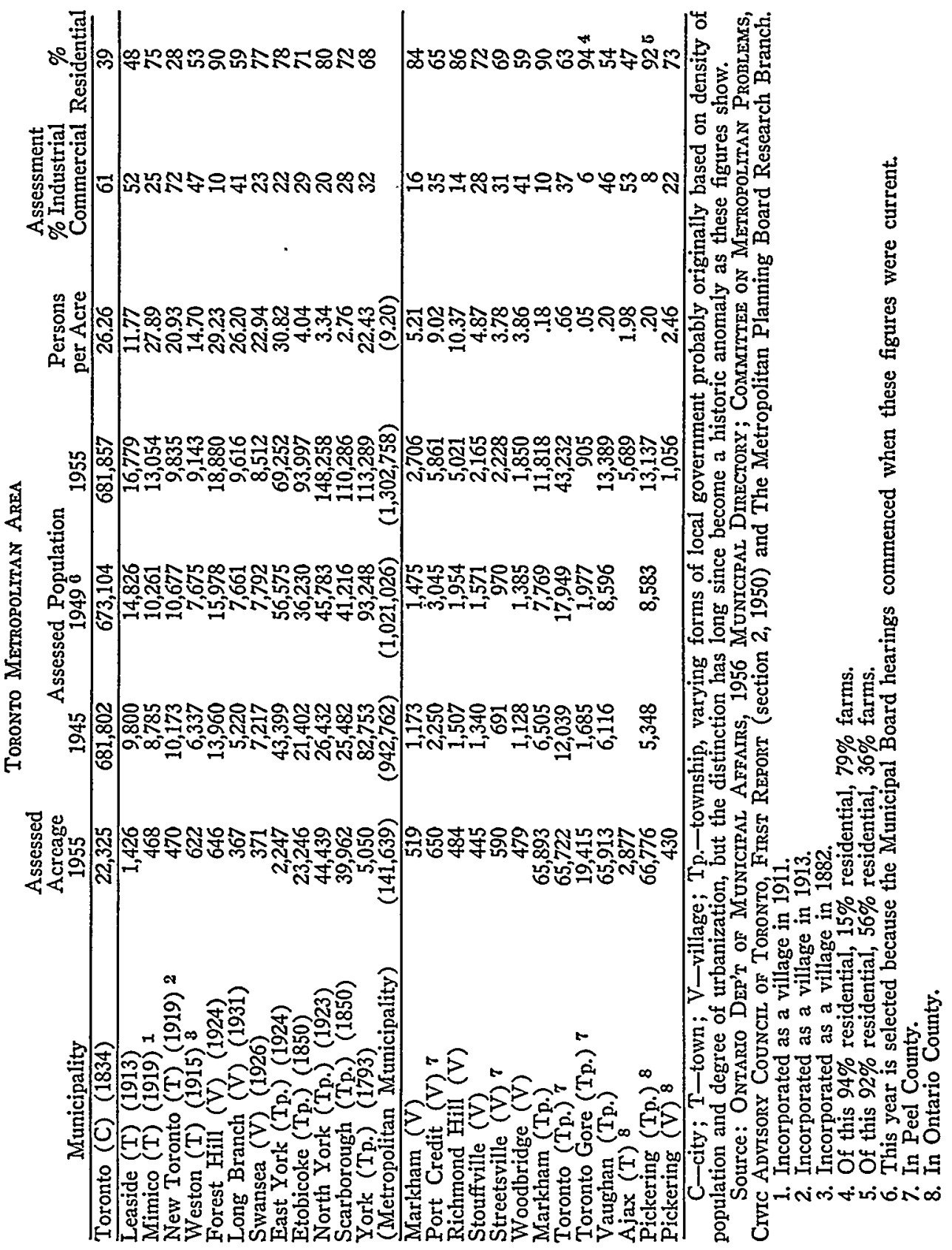


is not always a conclusive measure of a municipality's financial health. The village of Forest $\mathrm{Hill}^{3}$ is an interesting exception in this respect, for it has ninety per cent residential assessment, it is a fully-serviced municipality, but in 1955 had a mill rate of only 37.6 mills as compared with Toronto's 44.7 mills on an equalized assessment. The most striking incongruity in the area is the disparate bases in New Toronto with seventy-two per cent industrial assessment and in its immediate neighbor Mimico, with only twenty-five per cent industrial. If these two municipalities were to amalgamate, they would show an almost ideal balance. Together with Long Branch they comprise the area of the Lakeshore School Board, the only board in the area that prior to the federation combined two or more municipalities. A striking instance of lack of co-ordination of services was evidenced by the fact that eleven of thirteen police radio systems in the area were not interchangeable.

A familiar study of the Chicago metropolitan area accounts for over 1,600 local government units. ${ }^{4}$ By comparison the political problem of federating the municipalities of the greater Toronto area was simple. The thirteen municipalities included in the federation (shown in the first two divisions of the table) are all within the province, and all within York County. Even when the metropolitan area is broadened to include the official planning area, it includes only parts of three counties, one city, five towns, ten villages and ten townships (all the municipalities shown in the table). This makes a grand total of twenty-nine local government units, of which the three counties are already federations.

The Ontario conception of a county is far from universal. ${ }^{5}$ Counties are not of uniform size and they do not include cities within their boundaries for municipal purposes other than the administration of justice. Some towns are also separated from the county for municipal purposes, but there were no separated towns in the metropolitan area. The thirteen municipalities within the federation form the southern quarter of the 882 square miles of York County. The York County Council is composed of the reeves and deputy reeves of the towns, villages and townships in the county. ${ }^{6}$ Its jurisdiction is limited to the

3. Forest Hill Village is generally supposed to be the community analyzed in SEELY, SIM \& LOOSLEY, CRESTWOOD HEIGHTS (1956).

4. MERriam, PARRATt \& LEPAWSKY, THE GoVERNMENT OF THE METRopolitan Region of Chicago 9 (1933), cited in Walker, ThE PlanNing FunCrion IN URBan GOVERNMENT 260 (1941) and Walker, Chicago, in GREAT CITIES OF THE WoRLD 191, 195 (Robson ed. 1954).

5. For an account of county government in Ontario and municipal government in Canada generally, see CRAWFord, CANAdTAN MUNICIPAL GovernMent passim (1954). See also Britrita, Local Government in CaNada (1951); Rowat, Your Local GOVERN MENT (1955).

6. Municipal Act, ONT. Rev. StAT. c. $243, \S 48$ (1950). 
establishment of a county road system, the administration of certain health and welfare services, a county jail and court house, and a number of minor matters. It raises its revenue by assessing the constituent municipalities who in turn raise the revenue as part of their general rate.

The core of the metropolitan area is the city of Toronto, which was incorporated as a city in 1834, with a population of some 9,000. The city grew continuously for the next eighty years, reaching out and swallowing up the urbanized fringe areas as they appeared and took form. Toronto was able to contain itself within its original boundaries until 1883, when it commenced a series of some forty-seven annexations, $^{7}$ the largest being of North Toronto, 2,701.6 acres, in 1912. After 1914, however, annexation practically ceased, probably because either Toronto or the suburb or both were convinced that it would prove too costly for one or the other. The city nevertheless continued to grow from a population of 445,575 in 1913 to 681,857 in 1955, but the rate of increase flattened out after 1930 when the population had reached 621,596 . During the same period the suburbs grew rapidly and assumed municipal form and political self-consciousness. The dates of incorporation are shown on the table.

Within the metropolitan area in 1953, only Mimico had a council term of two years. Toronto and the other eleven municipalities held annual elections. The city of Toronto was governed ${ }^{8}$ by a council consisting of eighteen aldermen from nine wards and four controllers and a mayor elected by general vote. ${ }^{9}$ The municipalities other than the city were governed by a mayor (in towns) or a reeve (in villages and townships) and a varying number of councillors, rarely more than a total of seven elected members.

The area also boasts some eighty boards and commissions, but, while the administration cannot be said to be council-dominated in the sense that that is true of England, the boards and commissions have fewer powers of government than the 1,600 accounted for in Chicago, which could directly initiate tax levies and issue debenture bonds. Some, such as the Toronto Transit Commission, have rate-fixing

7. The annexations are listed in CITx of Toronto, MUNICIPAL HandBook 65-67 (1956). There were fifteen annexations after 1914, the latest in 1954, but only one exceeded twenty-two acres, 93.8 acres annexed in 1920.

8. For a short account of Toronto's city government, see PLUNRET, MUNICIPAL Organizarion in Canada 121-30 (1955). The Municipal Handbook contains a multitude of facts about the city and "Metro." All thirteen municipalities are subject to the general legislation, principally the Municipal Act, ONr. REV. STAT. c. 243 (1950). There are no "city charters."

9. Compare Montreal, with a council of 100 members thirty-three of whom are appointed by various organizations in the city. See PLUNKETr, op. cit. supra note 8 , at 147-55. 
power, but limited and indirect borrowing powers. In Ontario not even a local council can issue debentures without first securing the approval of the Ontario Municipal Board, ${ }^{10}$ but politically and financially the ultimate responsibility for debenture borrowing rests with the council. The local governments facing the metropolitan problems, therefore, were the thirteen municipal councils.

\section{Administrative Atrempts at a Solution}

In 1947, Mimico, whose plight was as severe as any in the area, applied to the Municipal Board for an order ${ }^{11}$ creating an area for the joint administration of certain services: education, fire and police protection, administration of justice, health and welfare, planning, sewage disposal and public utilities, including transportation and main highways. The area was to include only the urbanized part of the thirteen municipalities without regard to the existing municipal boundaries. Before the application was heard by the Board, Toronto in 1950 applied to the Board for an order ${ }^{12}$ amalgamating the city with the other twelve municipalities. An application by Long Branch for an order amalgamating New Toronto, Mimico, Long Branch and Etobicoke was, with consent of counsel for Long Branch, postponed indefinitely. The hearings on the Mimico and Toronto applications commenced on June 19, 1950, and were concluded on June 7, 1951. The Board's decision ${ }^{13}$ is dated January 20,1953. Eighty-five witnesses gave oral

10. Ontario Municipal Board Act, ONT. Rev. Star. c. 262, §67 (1950). The Municipal Board is the administrative agency that supervises the exercise of many municipal powers. Zoning by-laws, for example, require board approval. Municipal Act, ONr. REv. Star. c. 243, \& 390(8) (1950). For an early account of the Board, see LASKIN, THe ONTARIo MUNICIPAL Board (unpublished thesis in Harvard Law School Library 1937). For a very sketchy account of the current scope of board jurisdiction, see Yates, Practice and Procedure Before the Ontario Municipal Board, in Pracrice aNd Procedore, Before Administrative TrIBUNals 43 (The Law Society of Upper Canada Special Lectures pt. 1, 1953) and for a more detailed account of zoning procedures, see Cumming, in Is Zoning Wagging the Dog?, in Planning 1955, at 112 and Milner, Administrative Appeals and Planning Legislation, in MUNICIPAL LAw 117 (The Law Society of Upper Canada Special Lectures pt. 2, 1956). Decisions of the Board are not published in any series, but annexation, arbitration and assessment appeal cases are reported in the Board's Ammul Report, the latest volume being 46-47, for 1951-1952.

11. See Municipal Act, Ont. Rev. Stat. c. 243, \$22 (now \$24), as amended, 3 Errz. 2, c. 56, \& 1 (Ont. 1954) and 4 Eliz. 2, c. 48, § 4 (Ont. 1955). Section 24 has forty-two subsections and constitutes a code governing the creation of inter-urban administrative areas. It was originally passed as $\S 5$ of the Municipal Amendment Act, 1946,10 GEo. 6, c. 60 (Ont.).

12. See Municipal Act, ONr. REv. Star. c. 243, § 12 (now § 14), as amended, 3 Euz. 2, c. 56, \$1 (Ont. 1954), a code governing annexations and amalgamations under board supervision.

13. Ontario MUnicipal Board, Decistons and Recomrmeindations (1953) (hereinafter cited as DECISIONS AND RECOMMAENDATIONS). These decisions will presumably be included in 48-49 ONTARIo MUNICIPAL BOARD, ANNUAL REPORT (19531954) (hereinafter cited as ANNUAL REPORT), which is in press. Meanwhile they have been specially published by the Queen's Printer, Toronto, the best short account of the circumstances preceding federation. Part 2 , dealing with the evidence, gives the general background. 
testimony and more than 300 exhibits were filed. The traditional thirteen municipalities as well as the county of York and the township of Toronto and some half dozen special boards or commissions in the area were represented at the hearings. ${ }^{14}$ The hearing of these applications represented the only formal opportunity for consultation with the municipalities now comprising Metropolitan Toronto. At no time was there a popular vote. ${ }^{15}$

The Mimico application may be discussed shortly. Mimico was quick to take advantage of an amendment to the Municipal Act in $1946,{ }^{16}$ which introduced a new section containing forty-one subsections making up a code for the "joint administration" of an interurban area by a board of management composed of one member from each ward in the area. The section could be invoked by any municipality on application to the Municipal Board. The application was opposed before the Board by all the other municipalities represented, including the city. Even counsel for Mimico preferred the city's proposal and asked the Board to approve Mimico's application only if the city's application should fail.

It is quite apparent that the Board accepted the principle of an inter-urban area for the administration of selected services as overcoming many of the objections to the city's proposal for outright amalgamation, but it rejected the proposal because the powers were wholly administrative and the board could not "plan or construct extensions or improvements of existing services or . . . build new schools, public works and other projects which might be needed throughout the area." 17 Perhaps the greatest of the other objections was duplication of the federal principle, for twelve of the thirteen municipalities to be included in the area were already part of York County and the inter-urban area could not be separated from the county. Whether the Board's rather strict interpretation of the Municipal Act was a necessary one, it may be conceded that the legislature probably had no thought, in 1946, that it was providing a solution to any municipal problem of the scope of the metropolitan area. In the interval between

14. Decistons and Recommendations 2.

15. Committee sessions of the legislature were of the whole house. The Municipal Board refused to direct a vote by the election of the city under \& 14(3) of the Municipal Act, ONr. REv. SrAT. c. 243 (1950), as amended, 3 Eliz. 2, c. 56 (Ont. 1954). The Board's reasons for refusal are referred to but not repeated in DEcIsIoNs AND RFCommendations 6. See 45 ANNUAL REPORT 29 (1950), for the decision on the ground that no evidence was produced to show that the elected representatives did not represent majority opinion. supra.

16. Municipal Amendment Act, 1946, 10 Gæo. 6, c. $60, \S 5$ (Ont.); see note 11

17. Decisions and Racommendations 37. 
1946 and 1953, the power had been used only once, ${ }^{18}$ and the Board felt keenly the absence of experience with it.

The Board's unwillingness to grant the Toronto proposal is not too easily accounted for, unless the strong institutional opposition of eleven of the thirteen municipalities was taken as a democratic rejection of amalgamation. The city's proposal was a simple one in principle and in a sense historically consistent with past annexations. In another sense, however, the position was radical, for at no time had the city annexed more than five square miles whereas the total area to be amalgamated in the city's proposal was 239.7 square miles. And at no time had the city lost its own identity as it would with amalgamation, which might invite what the Board described as "prolonged administrative confusion of the most serious kind." 19 On the other hand, the city rightly recognized that if the suburbs opposed amalgamation, they would more strongly oppose annexation, which would result in only the city retaining its traditional corporate character and prestige. The suburbs would have been lost in the shuffle.

The Municipal Board did not minimize the many advantages of a completely centralized and consolidated form of local government, but it found four "serious objections" to amalgamation. The first was the administrative confusion already referred to. The administrative organizations and procedures in the thirteen governments are quite varied and the process of superimposing uniformity would undoubtedly be painful, but the Board hardly established that it would be either impossible or even more difficult than the kind of federal solution ultimately adopted, nor did the Board consider how amalgamation might be achieved by enacting new procedures.

The second objection ${ }^{20}$ was that amalgamation would result in higher taxation due to the "practical necessity" of bringing all suburban wage and salary scales and working conditions up to city levels. It is not obvious that this difficulty would be avoided in a federal scheme either, since the same necessity would arise in those municipal services taken over by the new federal administrative area. Depending on the degree of centralization, the preference for federation loses its strength and attractiveness on this count.

The third and fourth objections were founded on the Board's belief that a single government could not be expected to deal "wisely and adequately with both local and metropolitan problems" and the

18. Unreported. The Board seemed doubtful about the number of times the powers had been used. See ibid.

19. Id. at 28 .

20. Id. at 29 . 
Board's conclusion that, "although the type of government proposed by the city might be strong, efficient and well organized, it would not be local government." 21 It may be that the Board instinctively recognized the political weakness of its position: ${ }^{22}$ the solution to the metropolitan problem in the Toronto area involving over a million persons living over an area of 240 square miles might be better dealt with by the provincial legislature, a politically responsible body, rather than an administrative tribunal consisting, in this case, of two men, admittedly both of wider knowledge and experience in municipal affairs than probably any member of the Ontario legislature, but still appointed, not elected, persons. How else can one account for the extraordinary judgment that city government over an area of only 240 square miles and one million residents is not local government?

Although the Board had, in dismissing both applications, discharged its statutory duty, because of its "unique opportunity" to review the metropolitan situation it proceeded to "recommend without qualification" a plan of federal metropolitan government which it outlined in the concluding fifty pages of its decision.

The Board's recommendations follow its finding that the applicants had clearly proved the need of some major reform of the existing form of local government. In substance the recommendations are similar to the solutions adopted by the legislature, and further reference will be made only to the few instances where the legislature adopted a materially different solution.

\section{The Ontario Legislature's Solution}

An Act To Provide for the Federation of the Municipalities in the Toronto Metropolitan Area for Certain Financial and Other Purposes ${ }^{23}$ constituted the inhabitants of the thirteen municipalities a body corporate under the name of "The Municipality of Metropolitan Toronto" on April 15, 1953. At the first reading of Bill 80 on February $25,1953,{ }^{24}$ the Premier said that he had intimated to the chairman of the Municipal Board that whatever its decision might be, it was

21. Id. at 29-31. at 32

22. But see the Board's own assertion of its readiness to exercise its powers in id.

23. 2 ELIz. 2, c. 73 (Ont. 1953). The capitalized words are the long title. The short title is The Municipality of Metropolitan Toronto Act, 1953. Hereinafter it is called simply the Act or the Metro Act. It has been twice amended: An Act To Amend the Municipality of Metropolitan Toronto Act, 1955, 4 ExIz. 2, c. 50 (Ont:) and An Act To Amend the Municipality of Toronto Amendment Act, 1956, 4 \& 5 ELIz. 2, c. 53 (Ont.). The original act is commonly still referred to as Bill 80 , under which number it was introduced in the legislature.

24. ONt. Deb. 24th Leg., 3d Sess. B 4 (1953). Ontario debates are published but are not widely distributed. 
inevitable that there be an appeal to the legislature and he would welcome the Board's views. The general effect of the act, which corresponds very closely to the Board's recommendations, is to transfer specific municipal powers ${ }^{25}$ from the constituent municipalities to the metropolitan municipality and to establish a council to exercise those powers. The organization of the new municipality is very similar to that of a county, but with much broader powers, and the twelve constituent towns, villages and townships were withdrawn from the county of York for municipal purposes. ${ }^{26}$

The Municipal Board had recommended ${ }^{27}$ a "purely temporary" council, for a "fairly long" and "critical" initial period of operation, of nine appointed members. The Board also recommended a minimum term of office of three years, but recognized at the same time that four or five years would be more satisfactory.

The legislature rejected the Board's recommendation for the constitution of the council, probably following the Premier's lead that "the people themselves have not the power to appoint their representatives."28 That objection does not, however, account for the rejection of the proposed three-year term. The Metropolitan Council has twenty-five members, ${ }^{29}$ twenty-four of whom were originally to be elected for one year, and it was only in 1956 that the term was lengthened to two years, a slow step toward urgently needed reform..$^{30}$ The twenty-four members include the head of the council in each area municipality, and from the city eleven more representatives: the two controllers who received the highest number of votes at the preceding election, and the alderman who received the higher number of votes from each of the nine wards. These members are equally divided between the city and suburbs, and the Council was authorized to elect as chairman one of the members of the council or any other person to hold office for that year. Mr. Fred Gardiner, Q.C., was appointed chairman by the LieutenantGovernor in Council for the remainder of 1953 and the term of 1954, but he was elected in 1955 and again in 1956.

This basis of representation is clearly a compromise and cannot be expected to last much longer. In the city, ward population varies from

25. Metro Act gives no general powers to the federal council. Under the Municipal Act, ONT. Rev. Stat. c. $243, \$ 260$ (1950) : "Every council may pass ... by-laws . . for the health, safety, morality and welfare of the inhabitants ..." This section is rarely resorted to since most by-laws powers are expressly set out. See particularly id. $\S \S 386-88$.

26. Metro Act pt. VIII, particularly $\$ 136$.

27. Dicisions AND RECOMMENDATIONS 83-85.

28. ONr. Dek. 24th Leg., 3d Sess. B 18 (1953).

29. Metro Act $\$ \$(1),(4)$ and (5).

30. 4 \& 5 ElIz. 2, c. 53, § 2 (Ont. 1956). 
42,207 to $123,986 .^{31}$ In the suburbs, population varies from 8,512 to 148,258. The experience of the London County Council in England has shown that direct election to a metropolitan council is not impossible, and a redistribution could easily produce something more like representation according to population. The chairman of the Metropolitan Council recently observed that the members of council had already "adopted the metropolitan concept" and rarely voted on the basis of local interests. ${ }^{32}$

The taxing powers of the Metropolitan Council are limited to levies against the area municipalities, after the manner of county councils, and apportioned among the area municipalities in the proportion that the whole taxable property in each area municipality bears to the whole taxable property in the metropolitan area, according to the last revised assessment rolls. ${ }^{33}$ Obviously this taxing power required a uniform assessment throughout the area, and accordingly the act abolished all local assessment after December 31, 1953, and set up a single assessment department headed by an assessment commissioner for the metropolitan area. ${ }^{34}$

To avoid needless competition in the money market and to secure orderly and carefully timed municipal financing, the power of the area municipalities to issue debentures was terminated on December 31, 1953..$^{35}$ Since then all debenture borrowing for municipal purposes anywhere in the metropolitan area has been done by the Metropolitan Council. Even where money is borrowed for the purposes of an area municipality exclusively, the debentures issued are direct, joint and several obligations of the Metropolitan Corporation and all the area municipalities, although the whole of the taxes imposed for payment of the loan may have been levied only against the one municipality for whom the money was borrowed. ${ }^{38}$

While the Metropolitan Corporation's credit ensures an easier market for area municipality borrowing, this benefit also subjects the area municipality to the discretion of the Metropolitan Council which may be reluctant to pass a debenture by-law for a financially unsound municipality. Problems of priorities must also inevitably arise. To

31. City of Toronto, Municipal Handook 68 (1956).

32. Address by Chairman Fred Gardiner, Toronto Regional Group of the Institute of Public Administration of Canada, Nov. 19, 1956. The quotations are taken from the manuscript. The talk has not been published.

33. Metro Act $\S 190(1)$, (5). Public school levies are collected from non-Catholic taxpayers who are not separate school supporters. See id. $\$ \$ 190(3),(4)$ and the Separate Schools Act, ONr. Rev. Stat. c. 356, particularly \$56(1) (1950).

34. Metro Act $\$ \S 25,26$.

35. Id. § 193(3).

36. $I d . \S \S 193(1),(2)$. 
protect its interests an aggrieved area municipality was given a right of appeal to the Municipal Board which must hold a public hearing and inquire into the merits. ${ }^{37}$ No area municipality has yet made public any serious grievance resulting from a refusal of the Metropolitan Council to borrow, although the Metropolitan Executive Committee announced a temporary ban on borrowing on behalf of Scarborough, while a study was made of its ten year capital program. In the newspaper account ${ }^{38}$ of the announcement, Mr. Gardiner was said to have expressed concern over the unequal balance of Scarborough's industrial assessment. The Metropolitan Council is apparently still regarding a forty per cent industrial assessment as a minimum, despite the reallocation of school and other expenses over the whole metropolitan area. Such a high ratio would now seem higher than necessary.

Apart from the financial reforms, probably school administration was the most important reallocated municipal function. The burden of schools weighed heavily on those municipalities whose tax base was substantially residential assessment--particularly in the rapidly expanding townships of Etobicoke, Scarborough and North York. To solve this problem a federal Metropolitan School Board, composed of ten members from the city, including the chairman of the city board of education and one member from each of the nine wards represented on the city board, and the ten chairmen from the suburban school boards, was created. In addition, two representatives are appointed by the Toronto and Suburban Separate School Board, one of whom must be a resident of the city and the other a resident of one of the suburbs. ${ }^{39}$ The chairman of the school board, like the chairman of the Metropolitan Council, could be selected from outside the twenty-two members, but the board was evidently able to put its confidence in one of its own members. The representatives from the separate school board do not take part in debate exclusively affecting the public schools.

The board has wide powers to coordinate local school board proposals for provision of adequate public elementary and secondary school accommodation in the metropolitan area. ${ }^{40}$ In particular, the board must make "maintenance assistance payments" at present amounting to $\$ 150$ per annum for each public elementary school pupil, $\$ 250$ per annum for each academic secondary school pupil and $\$ 300$ per annum for each vocational secondary school pupil. ${ }^{41}$ The board raises its revenue

37. $I d . \S 195$.

38. Globe and Mail (Toronto), Nov. 30, 1955, p. 1, col. 5 .

39. Metro Act $\S 119$. See generally id. pt. VII.

40. Id. $\$ 126$.

41. Id. $\S 125(2)$. These amounts are a rough average of municipal school expenditures per child per year. 
by submitting annually to the Metropolitan Council estimates for the current year, and the corporation must pay the amount required, ${ }^{42}$ which in turn it raises by levy on the area municipalities. Future debentures for school purposes must, of course, be issued in the name of, and on the credit of the metropolitan corporation. ${ }^{43}$ Local boards continue to have all powers, duties and responsibilities previously held that are not inconsistent with those of the new board. ${ }^{44}$ This retention of power enables area municipalities to provide a higher standard of education than the metropolitan board will pay for, if the local board and council are willing to bear the extra expense, as many are doing now. . $^{4}$

The legislature's second substantial deviation from the Municipal Board's recommendation was in the formation of the Metropolitan School Board. The Municipal Board had been quite content to place all the federal powers of co-ordinating and financing in the metropolitan council, leaving it in a position "comparable with that of an ordinary municipal council with relation to its local boards." 46 It is difficult to see what has been gained by the creation of a metropolitan school board, but the Premier, in introducing Bill 80, objected to the Board's view because it differed from "the traditional method existing in this province." 47 The Board's recommendation, of course, was part of its general proposal, which contemplated a three-year term of office for the council. Undoubtedly less confidence could be felt in the judgment of a one-year council, but now that the council term is two years this longer term may be accompanied by a greater political stability, which would justify greater political responsibilities. "Tradition" seems an odd excuse for the Premier to have advanced when he was introducing such an untraditional proposal as federation.

The water supply and sewage and drainage problems were turned over to a metropolitan water works system and a metropolitan sewage works. The Metropolitan Council, rather than an independent commission recommended as "particularly advantageous" by the Municipal Board, assumed all works for production, treatment and storage of water in each area municipality, and all trunk distribution mains. ${ }^{48}$ The metropolitan corporation must supply water to the area munic-

42. Id. $\$ 126(1)(\mathrm{j}), 127$.

43. Id. $\$ 193(1)$; see $i d . \S 193(3)$. Protection is given to the local school board and local council. $I d$. $\$ \$ 132,133$.

44. Id. $\S 129(2)$.

45. Decisions and Recomamendations 58

46. Id. at 57 .

47. 1 Onr. Dek. 24th Leg., 3d Sess. B 18 (1953).

48. See generally Metro Act pts. III, IV. 
ipality, and the local council or board is responsible for local distribution, but must maintain metropolitan standards. No compensation is payable, but the Metropolitan Council assumes the debenture debt. ${ }^{49}$ If an area municipality is dissatisfied with the extent of metropolitan operation, it may appeal to the Municipal Board. ${ }^{50}$ In a talk ${ }^{51}$ last November, Mr. Gardiner estimated that by 1958 or 1960, at a cost of $\$ 170$ million, metropolitan Toronto will have an adequate water supply and drainage system throughout the settled portion of the whole area.

The need for arterial roads was met by the establishment of a metropolitan road system ${ }^{52}$ on principles very similar to those applicable to county roads. Two arterial routes are well under way, and two more are in the planning stage but are subject to the priority that may be given to rapid transit extension, a service more needed than arterial roads, which bring more cars to the central city but do nothing to solve the parking problem. The Toronto Transportation Commission, which provided rapid transit and public transport service generally within the city, and by special contract outside the city, gave way to the new Toronto Transit Commission which now has all the rights and privileges in respect of the entire metropolitan area which the former commission had with respect to any part of the area..$^{53}$

Health and welfare services and the care of court houses and jails, municipal services that in the past have been shared by local municipalities and the county, are now carried by the Metropolitan Council and shared to a limited extent by York County. ${ }^{54}$ The Council can now claim credit for two aged persons' homes and the acquisition of three new sites. Over a period of ten years at a cost of about ten million dollars it hopes to solve the problem of housing for aged persons. A moderate rental housing project of 1,100 units to accommodate 3,500 to 4,000 people at rentals of fifty-eight to seventy-eight dollars per month is under construction. This is a partnership project between

49. Id. 37(5). This subsection illustrates a common pattern throughout the act where the metropolitan corporation assumes an asset of an area municipality. Metro pays to the area municipality before the due date all principal and interest becoming due on a debenture issued in respect of the asset. Default by Metro entitles the area municipality to charge Metro with interest at the rate of one-half of one per cent for each month or fraction of a month the payment is overdue. Any dispute over relation of debenture to asset is to be settled by the Municipal Board whose decision is final. Id. $\$ \$ 37(6),(7)$. See also $\$ \$ 28,61(5)-(7), 99(1)-(3), 104(1)-(4)$.

50. Id. $\S \S 50,68$.

51. See note 32 supra.

52. Metro Act pt. V.

53. Id. pt. VI.

54. Id. pts. IX, X. 
the federal, provincial and metropolitan governments. Bearing in mind the Premier's interest in housing, ${ }^{55}$ this record is not, perhaps, impressive, but the water and sewer works represent big steps forward. The housing provisions conferred upon the metropolitan corporation and council the same housing powers other municipalities have under general legislation, without reducing the housing powers of the area municipalities in any way. ${ }^{56}$ These powers were recommended by the Municipal Board despite the contention of some of the respondent municipalities that "the provision of any type of subsidized or publicly assisted housing should not be considered a proper function of municipal government." 57

The power to acquire land for parks and open space was not apparently dealt with at any length in the hearings before the Municipal Board, but the Board regarded some metropolitan power to establish new parks and to assume existing ones as a "matter of great urgency and importance." 58 The Metropolitan Council may establish parks and open spaces not only in the metropolitan area but also in the adjoining local municipalities in Ontario and Peel counties and in any local municipality in York County. ${ }^{59}$

No mention was made of the police problem in the original act, but by 1956 increasing confidence in the metropolitan council's ability to handle more federal jurisdiction led to the creation of a Metropolitan Board of Commissioners of Police, ${ }^{60}$ to commence operations on January 1, 1957. The metropolitan police force will take over the staff of the area police forces, which will present special difficulties arising out of the great disparity of rank, salary and experience evident among the various municipalities.

The 1956 amendment also created a Metropolitan Licensing Commission ${ }^{61}$ with jurisdiction to license a half-dozen trades from the many that may be licensed in this day of enlightenment. The licensing powers given to police commissions or local councils in area municipalities under general legislation may also be exercised by the Metropolitan Licensing Commission when so authorized by the Metropolitan Council. A local by-law then is of no force until the metropolitan commission vacates the field.

55. The Premier's speech introducing Bill 80 intimates that his chief concern in forming Metro was to spur housing. 1 ONT. DeB. 24th Leg., 3d Sess. B 14 (1953).

56. Metro Act pt. XI.

57. DeCISIONS AND RECOMMENDATIONS 69.

58. Id. at 73.

59. Metro Act. pt. XIII.

60. 4 \& 5 Eliz. 2, c. 53, § 18, pt. X-A (Ont. 1956).

61. Id. pt. X-B. 


\section{Planning and the Future}

In 1953 the general planning legislation of the province was the Planning Act, ${ }^{62}$ which contemplated planning by a local board in an area defined by the Minister of Planning and Development. The planning area had been York County, with local boards in contained "subsidiary areas," but the Toronto and York Planning Board and the planning area were dissolved by the act, and the Minister subsequently defined the Metropolitan Toronto Planning Area, which includes all the municipalities listed on the table. Of the twenty-six municipalities, only thirteen are within metropolitan Toronto for any other municipal function. The Board membership of thirteen includes no one who resides in the additional thirteen municipalities, although the planning board has already taken action that has conflicted with the planning of these outsiders. Fourteen of the municipalities had been defined as planning areas and had planning boards prior to the establishment of the metropolitan planning area as the superior unit. ${ }^{63}$

The principal instrument of planning is the "official plan," and the official plan of the metropolitan planning area will prevail over local official plans. The plans of subsidiary areas must be amended to conform and no future plan may be adopted that does not conform. And no public work may be undertaken, and no by-law passed, by a council or local board in any of the twenty-six municipalities, that does not conform with the plan. ${ }^{64}$ This broader planning area represents the biggest step yet taken in regional planning in Ontario, although the existing legislation permits any region to be defined as a planning area. The effect of the plan adopted by the Metropolitan Council without representation from one-half of the municipalities affected could be highly restrictive, and some feeling exists that there should be representation from the entire area. Representation could be nothing more than a token recognition of the fringe area interests, but in any event there is a real protection for the local municipality. Before a plan becomes "official" it must be approved by the Minister, ${ }^{65}$ and an aggrieved municipality can compel the Minister to refer the plan to the Municipal

62. ONT. Rev. Stat. c. 277 (1950), as amended, 15 GEo. 6, c. 65 (Ont. 1951) 1 Elrz. 2, c. 75 (Ont. 1952), 2 Eliz. 2, c. 80 (Ont. 1953). See Planning Act, 1955, 4 Eliz. 2, c. 61 (Ont.), as amended, 4 \& 5 Eliz. 2, c. 64 (Ont. 1956).

63. Local planning boards continue to operate within their "subsidiary areas." Planning Act, 1955, 4 ElIz. 2, c. 61, \& 2 (Ont). On April 15, 1953 there were seven official plans in effect. Since then eight more area municipalities have been defined as subsidiary planning areas and some have had plans approved. Four municipalities have so far ignored the permissive provisions of the Planning Act, 1955.

64. Metro Act $\$ 179(7)$.

65. Planning Act, 1955, 4 Elız. 2, c. 61, § 12 (Ont.). 
Board ${ }^{B 0}$ for approval after a hearing, whereas neither the planning board nor the Minister is obliged to hold any hearing.

The Metropolitan Planning Board is to study land use, means of communication, sanitation, green belts and park areas, public transportation and any other matters defined by the Minister. ${ }^{67}$ It has also assumed that it must relate its plans to the economic and financial position of the planning area. So far, however, the planning board has not completed its plan for submission to the Council, but while it is true to say that planning is behind rather than ahead of construction, interim planning is becoming more and more effective, and the board expects to have its plan ready this year.

At the 1956 session of the legislature the Ontario Water Resources Commission was established, ${ }^{68}$ with powers wide enough to put the supply of water and the disposal of sewage entirely under commission control. The commission's program could become the dominant consideration in the location of industry, and if the commission's planning is not co-ordinated with planning by the metropolitan and other planning boards, the commission's planning is likely to be controlling. Water and sewer systems are traditional municipal functions that may soon be lifted from the infant council to a still higher administrative unit. What is perhaps more important, the regional planning functions may be lifted with them, or even worse, regional planning functions may become even more divided than at present.

An appraisal of the achievements of metropolitan Toronto so soon after its incorporation is likely to be premature, for the experiment is still very much an experiment, but three vital problems are already causing concern, although they seem not to have been considered the business of the planning board or of any presently constituted body except the provincial legislature. First is the possibility of amalgamiation, or at least a change in the basis of representation on the Metropolitan Council. Originally only Mimico favored the Toronto proposal for amalgamation. In a newspaper report ${ }^{69}$ last November, heads of four suburban councils supported, and heads of three opposed, amalgamation; of first importance, perhaps, was the view attributed to Premier Frost, that amalgamation was no answer to criticism of the present system. Three other heads of councils expressed dissatisfaction with

66. Id. $\S 29(1)$.

67. This list of duties is not exhaustive, they are merely "included" in the scope and general purpose of the official plan. Metro Act $\S 181$. But the general provisions of the Planning Act also apply except where inconsistent with the Metro Act. Id. § 182 .

68. Ontario Water Resources Commission Act, 1956, 4 \& 5 Eriz. 2, c. 62 (Ont.).

69. Globe and Mail (Toronto), Nov. 23, 1956, p. 1, col. 1. 
area municipality representation. So far no authoritative body has considered these questions, but the Premier seems willing to have some committee study all the current criticisms.

The second problem is the transfer of further local powers to the federal council. In his talk last November, ${ }^{70} \mathrm{Mr}$. Gardiner lightly remarked that the Metropolitan Council would take over the fire department in a year or two. Transfers may, of course, be planned intelligently and openly, with participation by competent and representative voices from the area municipalities, but if so, no procedure now guarantees it and the whittling down of area municipalities can have disastrous results in the long run. A successful federation must have vigorous constituents, and if the residual powers of area municipalities are reduced much farther, the prestige of local representation, which is not high now, ${ }^{71}$ will dwindle to the point where responsible candidates will not be forthcoming. In that event amalgamation, however distasteful to some, will be the lesser of two evils, unless perhaps, a system of direct election could avoid both evils.

The third problem, and perhaps the most important, is the means of bringing new territory into the federal scheme. Many people believe some of the fringe municipalities should be adopted already. ${ }^{72}$ Apart from legislative amendment the only present possibility at an administrative level is by annexation or amalgamation by an area municipality of or with a "fringe" municipality, under supervision of the Municipal Board. ${ }^{73}$ The standing of the Metropolitan Council at the Board hearing is not defined in the act, although its interest is obvious. Annexation or amalgamation by the Metropolitan Council of or with any adjoining municipality is clearly impossible. Sooner or later the present federation might be amalgamated into one municipal unit and, with the remaining municipalities now only in the planning area, might become the constituents of a new federation. In this event the central city would be so much larger than the "new" suburbs that amalgamation of the present federation, followed

\section{See note 32 supra.}

71. Municipal political interest is not high if voting statistics are a fair indication. In the December 3, 1956 election, the first for a two-year term, the unofficial count was approximately $27 \%$ of the eligible voters. The vote in 1942 was only $19.94 \%$. Globe and Mail (Toronto). Dec. 4, 1956, p. 1, col. 8. Since 1949 the highest vote was in 1951, at 46.79\%. See City of Toronto, Municipal HandBook 56 (1956).

72. Toronto Township officials have in the past few years sent up trial balloons. The Committee on Metropolitan Problems included the Peel County municipalities of Port Credit and Streetsville villages and Toronto Township in their definition of the metropolitan area in 1949. They did not include the Ontario County municipality of Pickering Township, which is included in the metropolitan planning area. See note 1 supra.

73. Municipal Act, ONT. REv. STAT. c. 243, § 14 (1950). 
by annexation of the suburbs, might be more appropriate. In any event the metropolitan area is rapidly filling up ${ }^{74}$ and, if a repetition of the metropolitan problems is to be avoided, some procedure should be found to handle the adjustment gradually, rather than wait until major surgery is indicated.

74. The population of the metropolitan area is expected to double in the next twenty years. 